\title{
THE USE OF GUESSING GAMES IN IMPROVING THE SPEAKING SKILLS OF ELEMENTARY SCHOOL STUDENTS
}

\author{
Fitria Ayu Meningsih*, Suwarsih Madya \\ Yogyakarta State University, Indonesia \\ (fitriaayum@gmail.com)
}

Received: $16^{\text {th }}$ August 2021; Revised: $29^{\text {th }}$ October 2021; Accepted: $27^{\text {th }}$ December 2021

\begin{abstract}
Guessing game is a part of Communicative Language Teaching (CLT), which will create an atmosphere for students to increase the desire to learn languages. However, learning with games makes students undisciplined and requires a long time. This study aims to determine the effect of learning English using a guessing game method on the speaking skills of elementary school students. The study is a one-group pretest-posttest design implemented at the Islamic Elementary School in Yogyakarta. The study sample consisted of 68 students in grade 6 in 2019. The sampling technique used was total sampling. The measured learning outcomes are speaking skills in pronunciation, vocabulary, grammar, fluency, and understanding. The data were processed using the Wilcoxon test. The results showed that the students' speaking skills improved after learning with guessing games. The speaking skills that improved significantly are pronunciation, vocabulary, and fluency. Grammar and comprehension, on the other hand, improved but not significantly. The conclusion is that the guessing game can improve the students' speaking skills even though it has not covered all of its aspects.
\end{abstract}

Key Words: communicative language teaching; elementary students; guessing games

\section{ABSTRAK}

Game menebak merupakan bagian dari Communicative Language Teaching (CLT) yang akan menciptakan suasana bagi siswa dalam meningkatkan keinginan untuk belajar bahasa. Namun pembelajaran dengan permainan membuat siswa tidak disiplin dan membutuhkan waktu yang lama. Penelitian ini bertujuan untuk mengetahui pengaruh pembelajaran bahasa Inggris menggunakan metode menebak terhadap keterampilan berbicara siswa sekolah dasar. Penelitian ini merupakan penelitian dengan menggunakan desain satu grup dengan pre tes dan pasca tes yang dilaksanakan di Madrasah Ibtidaiyah Yogyakarta. Sampel penelitian berjumlah 68 siswa kelas 6 tahun 2019. Teknik pengambilan sampel yang digunakan adalah total sampling. Hasil belajar yang diukur adalah keterampilan berbicara berupa pengucapan, kosakata, tata bahasa, kefasihan, dan pemahaman. Data diolah menggunakan uji Wilcoxon. Hasil penelitian menunjukkan bahwa keterampilan berbicara siswa meningkat setelah melalui proses pembelajaran dengan permainan tebak-tebakan. Keterampilan berbicara meningkat secara signifikan adalah pengucapan, kosa kata dan kefasihan. Tata bahasa dan pemahaman meningkat tetapi tidak signifikan. Kesimpulannya adalah bahwa permainan tebak-tebakan dapat meningkatkan keterampilan berbicara siswa meskipun belum mencakup semua aspeknya.

Kata Kunci: pengajaran bahasa komunikatif; siswa sekolah dasar; permainan tebak-tebakan

How to Cite: Madya, S., \& Meningsih, F. A. (2021). The Use of Guessing Game in Improving the Speaking Skills of Elementary School Students. IJEE (Indonesian Journal of English Education), 8(2), 327-3339. doi:10.15408/ijee.v8i2.21679

\footnotetext{
* Corresponding author
}

IJEE (Indonesian Journal of English Education), 8(2), 2021, 327-339

P-ISSN: 2356-1777, E-ISSN: 2443-0390 | DOI: http://doi.org/10.15408/ijee.v8i2.21679

This is an open access article under CC-BY-SA license (https://creativecommons.org/licenses/by-sa/4.0/) 


\section{INTRODUCTION}

English is an essential language to learn, especially in daily conversation, because English is an international language used globally. These conditions lead to the perception that it is necessary to master English from a young age. English is taught in elementary schools (Dzanic \& Pejić, 2016). Nevertheless, the importance of teaching English at the elementary level is still debated. Kasihani (2007) explained that the cognitive abilities of a 10-year-old child would develop when he or she is taught a foreign language, including English. Teaching English skills to the primary level is different from higher levels. There is a phase shift from the egocentric phase to the reciprocal phase. There is also a shifting in the child's view by seeing things from his perspective into seeing phenomena from another point of view.

The effectiveness of teaching the English language to the children is related to increasing the children's interest and making English teaching more interesting (Dzanic \& Pejić, 2016). Therefore, the teacher's role in the teaching process is significant, so teaching English to elementary school children will be fulfilled well. The teacher's role is an essential factor in the learning process. In achieving learning success, teachers need appropriate methods (Aji \& Budiyono, 2018).
Generally, good teachers always try to use the most effective teaching methods and use the right teaching aids or media. Likewise, in choosing material, the teacher must adjust to the ability level of students' interests and needs. In addition to the teachers, schools also have a significant role because schools form the curriculum as a legitimate educational institution (Sukmahidayanti, 2015).

One of the English language learning techniques applied to elementary school children is games. Games are part of communicative language teaching (CLT), a learning technique that can increase students' desire to learn English by conditioning the learning atmosphere. Games relax the learning environment, eliminate fear and enhance the practice for students. Games are also funny and exciting, motivating students to learn English speaking skills (Al-Jarrah et al., 2019).

Several studies support the use of games as a medium in learning as it can improve grammar skills (Haryanto, 2015), increase learning motivation and speaking skills (Ho et al., 2019), improve listening skills, and encourage students to move forward and be active in language practice (Valipour \& Aidinlou, 2014). However, there is a negative assumption about game 
learning techniques: games have no educational value and waste time (Freitas, 2019). While some teachers consider game learning techniques to have educational value, they rarely use them because they are challenging. After all, games are not suitable for onehour learning, and in single lessons with one teacher, game learning can be ineffective (Freitas, 2019; StojkoviĤ \& JerotijeviH, 2011). Games also cause noise in the classroom so that they are considered not to form discipline. There are no instructions/rules, so they are considered to deviate from the purpose and inadequate learning time, and the games used are commonly used by students so that students become bored

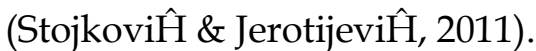

The difficulties and negative assumptions can be overcome if much evidence strengthens the use of games as a learning technique to improve learning outcomes. Several researchers have reported the use of guessing games in improving speaking skills. (Maqfirah et al., 2018) examined junior high school students in Banda Aceh with the results that guessing games increased students' fluency in speaking skills. (Dewi et al., 2016) researched junior high school in Kuta Utara, showing that $60.68 \%$ of students strongly agree with guessing games in improving speaking skills. (Nirwaty, 2020) examined in class VIII A of SMPN
1 Tanjungpinang with the results that guessing games were more effective and could improve students' speaking achievement. (Ai-Hayati, 2020) examined senior high school students in Cikasungka with the result that there was a significant difference in students' speaking ability between those taught by learning games and those who were not. (Ayu \& Ayu, 2019) investigated the senior high school students in South Angkola South Tapanuli with the results that speaking skills could be improved through guessing games. The research was conducted on junior and senior high school students, and speaking skills were studied in general.

Previous studies examined the effects of guessing games on general speaking skills conducted on junior and senior high school students. Speaking skills consist of pronunciation, vocabulary, grammar, fluency, and understanding, whereas previous research has never focused on every aspect of speaking skills and only studied general speaking skills. In addition, elementary school students aged 6 to 12 years are still developing their first language skills in reading, writing complex, and mastering different vocabulary (Collier, 2014).

Research on the use of guessing games related to speaking skills in every aspect, namely pronunciation, 
vocabulary, grammar, fluency, and understanding, has never been studied before in elementary school students. Therefore, this study aims to determine the effect of learning English using the guessing method on elementary school students' speaking skills, including grammar, pronunciation, vocabulary, comprehension, and fluency. This study conducted a study of guessing games related to their impact on aspects of speaking skills in pronunciation, vocabulary, grammar, fluency, and understanding in elementary school students to find out what parts most influence the use of this learning method. This study is also expected to determine the appropriate learning method in improving speaking skills, especially for elementary school students.

\section{METHOD}

\section{Research Design}

This one group pretest-posttest design research was conducted in Islamic Elementary School, Yogyakarta. This research was conducted on a

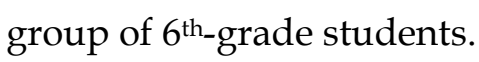

\section{Research Site and Participants}

The sample consisted of 68 students in 2019. The study population was the 6th-grade elementary school students. The sampling technique used was total sampling.

\section{Data Collection and Analysis}

This study used game cards for guessing games. The game card contains a picture and a question that the students randomly select. Then the students will guess what is in the picture. Each picture is in pairs then students are asked to find a pair. Each pair asked and answered according to the question on the card. The teacher's assessment consists of 5 measured aspects: grammar, vocabulary, pronunciation, fluency, and comprehension in speaking English. Thus, an assessment form was needed from the five aspects of speaking ability with five assessment categories from poor to excellent with a 1-5 score. The implementation of activities was carried out by researchers whom teachers observed. The teacher observed the teaching and learning process in activities carried out by the teacher and student participation. Research instruments used in data collection include field notes, observation sheets, and tests. The speaking skill assessment was carried out before and after the intervention.

The collected data were analyzed statistically with descriptive analysis to find the mean speaking skill between the post-test and pre-test. Furthermore, 
Furthermore, hypothesis testing is conducted to determine the difference between post-test and pre-test of speaking skills using paired $t$-test for normally distributed data and Wilcoxon's test for data not normally distributed at a significant level of $5 \%$.

The hypothesis proposed in this study is explained as follows: Ha: There is a significant difference in speaking skill scores between the pre-test and post-test. H0: There is no significant difference in speaking skill scores between the pre-test and post-test.

\section{FINDINGS AND DISCUSSION}

\section{Findings}

Comparison of the speaking skill mean scores on pre-test and post-test

This study measures speaking skills that consist of grammar, vocabulary, pronunciation, fluency, and comprehension. All aspects of speaking skills between pre-test and post-test are presented in Figure 1. Grammar describes the ability to use grammatical rules, while vocabulary describes the skills to use proper vocabulary in speaking. Pronunciation describes the ability to pronounce words according to their meaning. Fluency describes the fluency in speaking English, comprehensively describes the ability to capture the conversation of friends/teachers in English.

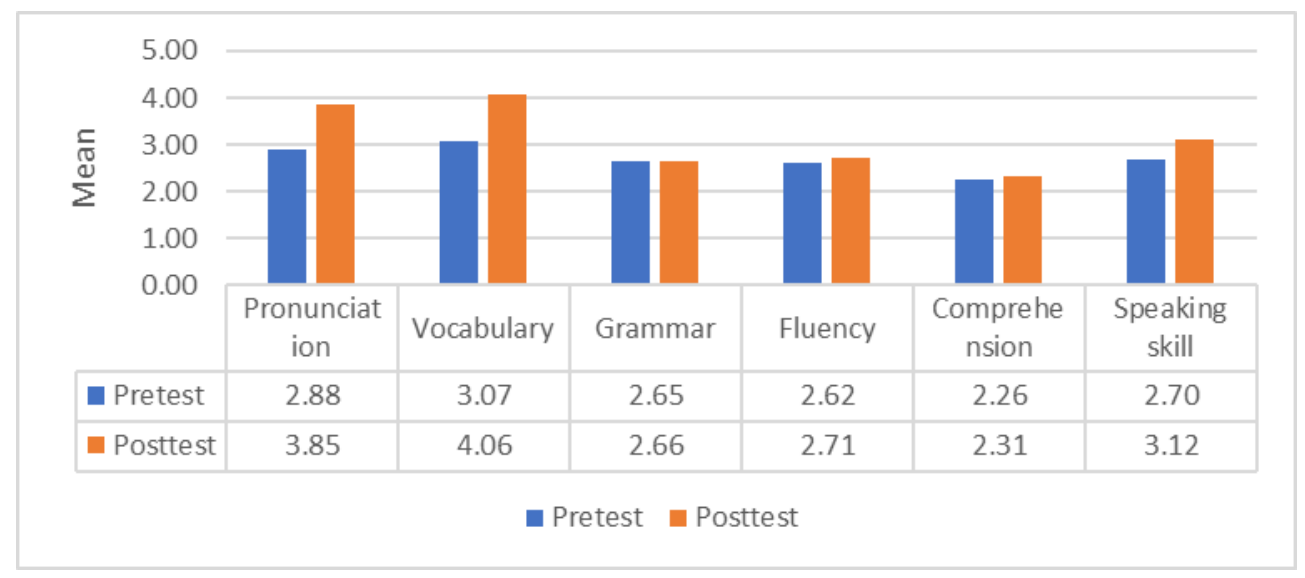

Figure 1. Histogram of the Mean Speaking Skill between Pre-test and Post-test

All aspects of communication skills showed that the mean of communication skills on the post-test is greater than that of the pre-test. These results indicate that the intervention in learning English using the guessing 
game method has improved all aspects of the students' speaking skills. The speaking skill which increased the most is in the vocabulary aspect, while the speaking skill which increased the lowest is comprehension. Vocabulary skills have improved from moderate to good.

\section{The Results of the Normality Test}

Table 1. Kolmogorov-Smirnov Normality Test Result

\begin{tabular}{lllll}
\hline Variable & & Statistic & $\mathrm{df}$ & $\begin{array}{l}\mathrm{p} \\
\text { value } \\
\text { s }\end{array}$ \\
\hline Pronun & Pre-test & 0.422 & 68 & 0.000 \\
ciation & Post-test & 0.342 & 68 & 0.000 \\
Vocabu & Pre-test & 0.401 & 68 & 0.000 \\
lary & Post-test & 0.402 & 68 & 0.000 \\
Grammar & Pre-test & 0.314 & 68 & 0.000 \\
& Post-test & 0.457 & 68 & 0.000 \\
Fluency & Pre-test & 0.419 & 68 & 0.000 \\
& Post-test & 0.408 & 68 & 0.000 \\
Compre & Pre-test & 0.445 & 68 & 0.000 \\
hension & Pos-tets & 0.359 & 68 & 0.000 \\
Speaking & Pre-test & 0.180 & 68 & 0.000 \\
skill & Post-test & 0.164 & 68 & 0.000 \\
\hline
\end{tabular}

Results of Kolmogorov-Smirnov with Lilliefors correction normality tests for all speaking skill aspects are shown in Table 1. It is clear that all speaking skill aspects have a p-value are less than 0.05 . Thus, all data are not normally distributed. Therefore, hypothesis testing was done by using the Wilcoxon test.

\section{Hypothesis Test Results}

Hypothesis testing is conducted to test the significance of the difference in the mean score of speaking skills between the pre-test and post-test using the Wilcoxon test with a significance level of $5 \%$. The Wilcoxon test results are shown in Table 2.

Table 2. Wilcoxon Test Result

\begin{tabular}{|c|c|c|c|c|}
\hline Variable & & Mean & Z & $\begin{array}{l}\mathrm{p} \\
\text { value } \\
\mathrm{s}\end{array}$ \\
\hline Pronunci & Pre-test & 2.88 & -8.124 & 0.000 \\
\hline ation & Post-test & 3.85 & & \\
\hline Vocabul & Pre-test & 3.07 & -7.606 & 0.000 \\
\hline ary & Post-test & 4.06 & & \\
\hline Gramma & Pre-test & 2.65 & -1.000 & 0.317 \\
\hline$r$ & Post-test & 2.66 & & \\
\hline Fluency & Pre-test & 2.62 & -2.449 & 0.014 \\
\hline & Post-test & 2.71 & & \\
\hline Compre & Pre-test & 2.26 & -1.732 & 0.083 \\
\hline hension & Post-test & 2.31 & & \\
\hline Speakin & Pre-test & 13.49 & -7.590 & 0.000 \\
\hline g skill & Post-test & 15.59 & & \\
\hline
\end{tabular}

The speaking skill aspect in pronunciation resulted in a p-value of 0.000 , lower than 0.05 , so $H$ ) was rejected. This means a significant difference in pronunciation scores between the pre-test and post-test.

The speaking skill aspect in vocabulary resulted in a $p$-value of 0.000 , lower than 0.05 , so $\mathrm{H} 0$ was rejected. It means a significant difference in vocabulary scores between the pre-test and post-test.

The speaking skill aspect in vocabulary resulted in a p-value of 
0.317 , more significant than 0.05 , so $\mathrm{H} 0$ was accepted. This means that there is no significant difference in grammar scores between the pre-test and posttest.

The speaking skill aspect in fluency resulted in a p-value of 0.014 lower than 0.05 , so $\mathrm{H} 0$ was rejected. This means a significant difference in fluency scores between the pre-test and post-test.

The speaking skill aspect in comprehension resulted in a p-value of 0.083 , more significant than 0.05 , so $\mathrm{H} 0$ was accepted. This means that there is no significant difference in comprehension scores between the pretest and post-test.

Overall speaking skill resulted in a p-value of 0.000 , lower than 0.05 , so H0 was rejected. This means a significant difference in speaking skill scores between the pre-test and post-test.

\section{Discussion}

Overall, it shows that the speaking skills of elementary school students differ significantly from before and after learning using guessing games. Speaking skills improved after learning using guessing games. Speaking skills that improved significantly after learning with guessing games included vocabulary, pronunciation, and fluency, but not grammar and comprehension.
In this study, teaching English using guessing games contained rules such as not mocking and cheering on friends who answered incorrectly. On the contrary, they were given rules to appreciate each friend who answered with applause. Students become motivated to attend lessons happily and do not feel anxious and worried about doing them even though they cannot. It means that the child dares to try to pronounce the English word. These results align with Ho et al.'s (2019) research that games can increase learning motivation and speaking skills. A similar result was reported by (Wang et al., 2011) that games could motivate students to learn English. The low ability of English could be caused by anxiety due to peer pressure. This is proved by the finding, which shows the students with high English proficiency have low anxiety due to peer pressure. (Leo \& Cely, 2010) explained that students with low English proficiency have a high fear of expressing themselves. Learning English through games can reduce anxiety from peer pressure, motivate and master vocabulary. Games create a comfortable atmosphere and make students confident in completing spoken English assignments, especially during game activities.

In this study, the mean score of pronunciation is significantly different, 
where the mean score in the post-test is higher than the pre-test. This showed an increase in pronunciation ability after learning with guessing games. Pronunciation is a way of saying words in general. English pronunciation is different, and it causes difficulties for some individuals. The sounds pronounced in different words in English are sometimes similar to each other, making it difficult to distinguish, and it is complicated to understand what a native speaker is saying (Hidayatullah, 2018). These results align with (Timothy et al., 2020) that students' pronunciation skills increase after learning with a broad game, "Word Detector." However, different results were reported by (Leong \& Ahmadi, 2017) that game is effective communication that can be developed through increasing skills in speaking, but many students difficult to express language lessons in pronunciation. They have difficulty expressing what will be said in learning a foreign language. These obstacles sometimes make people no longer want to speak due to psychological constraints and do not find appropriate words to express them.

In this study, the mean vocabulary score is significantly different, where the mean score in the post-test is higher than the pre-test. This showed that vocabulary increased with learning games because they heard what their friends said, recorded. They were also asked to chat with pairs of friends based on the questions on the cards, which made them apply the vocabulary in conversations that made the students remember them even more. The conversation is carried out between students to relax the atmosphere compared to the teacher. This result is in line with (Huyen \& Nga, 2003) that the students are helped in learning vocabulary through positive attitudes in the game. Games make it easy for students to understand and remember new words that could be directly applied to the vocabulary in a relaxed and comfortable conversation. Learning by using games also creates interaction from students with other students and teachers and gets motivated to speak English.

Vocabulary is one of the three elements of language, building materials, and the basis of language. Fluent in communicating with others must have a specific vocabulary. Faced with so many words to learn, it is necessary to investigate lean vocabulary strategies (Bai, 2018). The voice is an essential factor in increasing the vocabulary of learners. Therefore, students will have an advantage when they listen to good sayings from the teacher, quality recording, quality 
stories, and so on (Lumettu \& Runtuwene, 2018).

The results of this study increased the fluency speaking skills after learning for threthree months of students where students were required to speak when the English learning process was by the rules set in the game. Students are asked to speak according to the picture on the card, randomly taken by the students. This is relevant to (Mudofir et al., 2019). In the first cycle of the learning process, students' English skills have increased significantly through the learning process with learning role-playing strategies. In addition, the results of student questionnaires also show that students are pleased and interested in implementing the role-playing learning strategy to improve students' English skills.

In this study, the mean score of grammar skill in post-test is higher than pre-test but was not significant. This is because teaching emphasizes speaking, which prioritizes the courage to try. Grammar is also learned in making sentences that will be conveyed when asking and answering questions with friends. The study results also showed an increase in the comprehension of speaking skills after the learning process with guessing games. However, it was not significant because the learning process was also short. Many students uttered inappropriate pronunciations and whose vocabulary was not fully known so that students became less comprehensive with such short learning. This result is not in line with previous research that educational games help create more interest, encourage the learning atmosphere, and the difficulties experienced by students in learning and the difficulties experienced by teachers in teaching grammar are reduced, making it easier for students to learn from experience (Al-Jarrah et al., 2019). Language games allow students to learn grammar freely or have significant autonomy because they can connect their minds from the knowledge they have with their use (Butler, 2017; Yaccob \& Yunus, 2019).

In this study, the mean score of comprehension skill in post-test is higher than pre-test but was not significant. Comprehension is a complex cognitive process in which the reader deliberately interacts with text in an attempt to Derive Meaning, using a series of strategic actions to extract and construct understanding from language (Phuong, 2018). This result does not align with (Parikawati, 2019) that scramble games positively impact reading study comprehension skills in high school students. 
Thus, the learning process using guessing games has effectively improved the speaking skills of elementary school students, especially about vocabulary, pronunciation, and fluency. As explained in previous research, playing games is considered effective as a method or strategy for learning English, especially for young learners. It is also effective in teaching vocabulary mastery because students learn vocabulary not abstractly but concretely according to tangible objects (Wang et al., 2011).

Overall, games help improve students' speaking skills. As Freitas (2019) reported, games increase student motivation, are fascinating, and cause changes in behavior to be more active in learning, which impacts the results of good speaking skills. However, concerning speaking skills, guessing games in this study were not effective in improving grammar and comprehension. This can be related to the focus of what is conveyed in the game, a guessing game that emphasizes writing structures. This means that the improvement of speaking skills is not only related to interest, motivation, and pleasant atmosphere conditions, but it must also be studied carefully, what you want to convey in gameplay, the target to be achieved, and the minimum time required must be studied again. in various further studies.

\section{CONCLUSIONS AND SUGGESTION}

Communicative games through guessing games were a learning method that can improve elementary students' speaking skills in pronunciation, vocabulary, and fluency, but not in grammar and understanding. The limitations of the material presented and the short learning time can be the cause. This study implies that guessing games can be an alternative learning method for elementary school children to improve their English speaking skills, especially pronunciation, vocabulary, and fluency. The limitation of this study was that it was only conducted for three months, did not include the control group, and did not observe the student responses through observation in detail. Further studies can compare with the control group, evaluate for an extended period, and add data from observations during the learning process. In addition, it is necessary to develop learning materials using games to achieve more effective learning.

\section{REFERENCES}

Ai-Hayati. (2020). The Use of Digital Guessing Game to Improve Students' Speaking Ability. Journal of English Education and Teaching (JEET), 4(1), 115-126. 
Aji, W. N., \& Budiyono, S. (2018). The Teaching Strategy of Bahasa Indonesia in Curriculum. International Journal of Active Learning, 58(2), 58-64.

Al-Jarrah, J. M., Waari, O. T., Talafhah, R. H., \& Al-Jarrah, T. M. (2019). Improving English Grammar Achievement through Educational Games among Eleventh Grade Students in East Jerusalem. International Journal of Academic Research in Progressive Education and Development, 8(1), 75-86. https://doi.org/10.6007/ijarped/v8i1/5529

Ayu, K. S. I., \& Ayu, O. P. I. (2019). Developing Students Speaking Skill Trough Guessing Games. Yavana Bhasha: Journal of English Language Education, 2(2), 55. https://doi.org/10.25078/yb.v2i2.102 6

Bai, Z. (2018). An Analysis of English Vocabulary Learning Strategies. Journal of Language Teaching and Research, 9(4), 849. https://doi.org/10.17507/jltr.0904.24

Butler, Y. G. (2017). Motivational elements of digital instructional games: a study of young L2 learners' games designs. SAGE Journals, 21(6), 735-750.

Collier, V. P. (2014). The Effect of Age on Second Language Acquisition. Advances in Language and Literary Studies, $5(1)$ https://doi.org/10.7575/aiac.alls.v.5n. 1 p. 95

Dewi, R. S., Kultsum, U., \& Armadi, A. (2016). Using Communicative Games in Improving Students' Speaking Skills. English Language Teaching, $\quad 10(1)$, 63. https://doi.org/10.5539/elt.v10n1p63

Dzanic, N. D., \& Pejić, A. (2016). The Effect of Using Songs On Young Learners and Their Motivation for Learning English. NETSOL: New Trends in Social and Liberal Sciences, $\quad$ l(2), 40-54. https://doi.org/10.24819/netsol2016.8

Freitas, S. de. (2019). Are Games Effective Learning Tools? A Review of Educational Games. Journal of Educational Technology \& Society, 22(2), 14-25.

Haryanto, S. (2015). Teaching English Grammar With CLT and Explanation Method. Wahana Akademika, 2(2), 3. https://doi.org/10.21580/wa.v2i2.373

Hidayatullah, M. S. (2018). Improving Students' Pronunciation Through Western Movie Media. Journal AlLisan, 3(1), 93-111. https://doi.org/10.30603/al.v3i1.381

Ho, P. V. P., Thien, N. M., An, N. T. M., \& Vy, N. N. H. (2019). The Effects of Using Games on EFL Students' Speaking Performances. International Journal of English Linguistics, $\quad 183$. 
https://doi.org/10.5539/ijel.v10n1p18 3

Huyen, N. T. T., \& Nga, K. T. T. (2003). Learning vocabulary through games. Asian EFL Journal.

Leo, U. W., \& Cely, V. E. (2010). Encouraging Teenagers to Improve Speaking. Skills trough Games in Columbian. PROFILE, 12(1), 11-31.

Leong, L.-M., \& Ahmadi, S. M. (2017). An Analysis of Factors Influencing Learners' English Speaking Skill. International Journal of Research in English Education, 2(1), 34-41. https://doi.org/10.18869/acadpub.ijre e.2.1.34

Lumettu, A., \& Runtuwene, T. L. (2018). Developing the Students' English Speaking Ability Through Impromptu Speaking Method. Journal of Physics: Conference Series, 953(1).

https://doi.org/10.1088/1742-

6596/953/1/012035

Maqfirah, Y., Fitriani, S. S., \& Chairina. (2018). The Use of Guessing Games to Teach Speaking Skill. Research in English and Education (READ), 3(1), 91-99.

Mudofir, I., Maftuh, M. F., Supriyanto, M., \& Purwaningsih, H. (2019). Improving Fluency Skill in English Speaking Through Role Playing Learning Strategy at English Study Program, Administration Business Department, State Polytechnic of
Madiun. International Journal of Multicultural and Multireligious Understanding, 6(4), 52. https://doi.org/10.18415/ijmmu.v6i4. 934

Nirwaty. (2020). Guessing Game Activities To Improve Students' Speaking Skill At Grade Viii A Of Smp Negeri 1 Tanjungpinang. J-SHMIC: Journal of English for Academic, 7(1), 66-76.

Parikawati, M. A. (2019). The Effect Of Using Scramble Game On Students' Reading Comprehension Ability Of The Eighth Grade Student At Smpn 1 Mlandingan. UM Jember.

Phuong, B. H. (2018). Can using picture description in speaking sessions help improve EFL students' coherence in speaking? European Journal of Foreign Language Teaching, 3(3), 33-51. https://doi.org/10.5281/zenodo. 13100 86

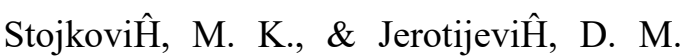
(2011). Reasons for Using or Avoiding Games in an EFL Classroom. 1st International Conference on Foreign Language Teaching and Applied Linguistics May 5-7 2011 Sarajevo.

Sukmahidayanti, T. (2015). The Utilization of Instructional Media in Teaching English toYoung Learners. Journal of English and Education, 2015(2), 90100. 
Timothy, J. A., Prasida, T. A. S., \& Prestilliano, J. (2020). Game Design As Learning Media of English Pronunciation Using Set Collection Mechanics. International Journal of Language and Literature, 4(1), 1. https://doi.org/10.23887/ijll.v4i1.302 20

Valipour, V., \& Aidinlou, N. A. (2014). the Effect of Language Games on Learning English Listening-Speaking Skills of Iranian Pre-School. Indian Journal of Fundamental and Applied Life Sciences, 4(2), 647-650.
Wang, Y.-J., Shang, H.-F., \& Briody, P. (2011). Investigating the Impact of Using Games in Teaching Children English. International Journal of Learning and Development, 1(1), 127. https://doi.org/10.5296/ijld.v1i1.1118

Yaccob, N. S., \& Yunus, M. M. (2019). Language Games in Teaching and Learning English Grammar: A Literature Review. Arab World English Journal, 10(1), 209-217. https://doi.org/10.24093/awej/vol10n o1.18 